\title{
Proteome-wide Lysine Glutarylation Profiling of the Mycobacterium
}

\section{tuberculosis H37Rv}

\author{
Longxiang Xie ${ }^{\mathrm{a} \perp}$, Guirong Wang ${ }^{\mathrm{b} \perp}$, Zhaoxiao $\mathrm{Yu}^{\mathrm{a}}$, Mingliang Zhou ${ }^{\mathrm{a}}$, Qiming Li ${ }^{\mathrm{a}}$, Hairong \\ Huang ${ }^{b *}$,Jianping Xie ${ }^{a *}$
}

a. Institute of Modern Biopharmaceuticals, State Key Laboratory Breeding Base of Eco-Environment and Bio-Resource of the Three Gorges Area, Key Laboratory of Eco-environments in Three Gorges Reservoir Region, Ministry of Education, School of Life Sciences, Southwest University, Beibei, Chongqing, China. b. National Clinical Laboratory on Tuberculosis, Beijing Key laboratory for Drug-resistant Tuberculosis Research, Beijing Chest Hospital, Capital Medical University, Beijing Tuberculosis and Thoracic Tumor Institute, Beijing, China 101149; 
Figure S1.(A) MS/MS spectra of a tryptic peptide ion TK(kg)PTSAGQADDALVR from Rv1347c; (B) MS/MS spectra of a tryptic peptide ion VEFEIGHSPK(kg)GPQATGVR from Rv3648c; (C) MS/MS spectra of a tryptic peptide ion PVPGWGSK(kg)RPR from Rv1259; (D) MS/MS spectra of a tryptic peptide ion $\mathrm{K}(\mathrm{kg})$ YTAPEISAR from dnak; (E) MS/MS spectra of a tryptic peptide ion $\mathrm{K}(\mathrm{kg})$ AIQSAMR from $\mathrm{rpsC}$; (F) MS/MS spectra of a tryptic peptide ion HAK(kg)GWNHFLDR from Rv0576.
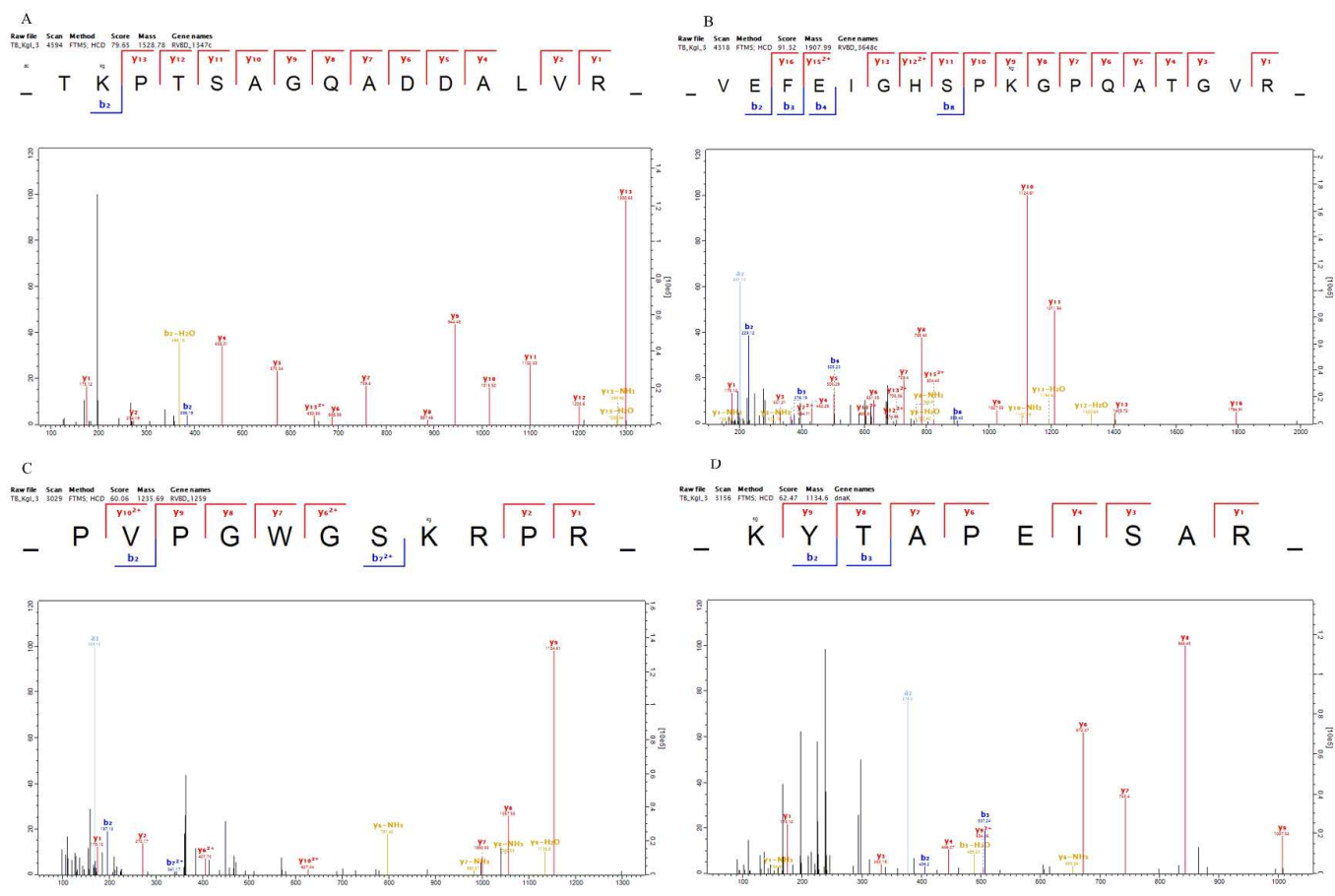

$(5$

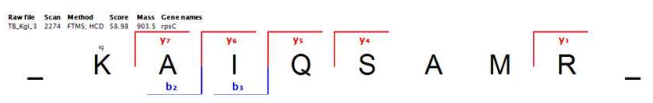

$\mathrm{F}$

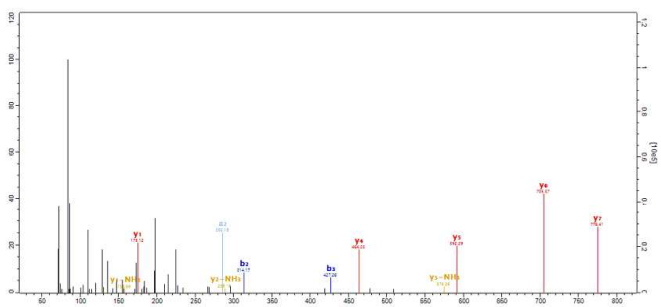

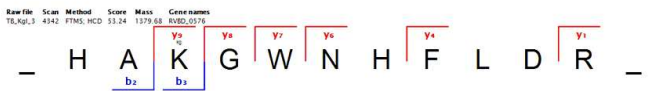

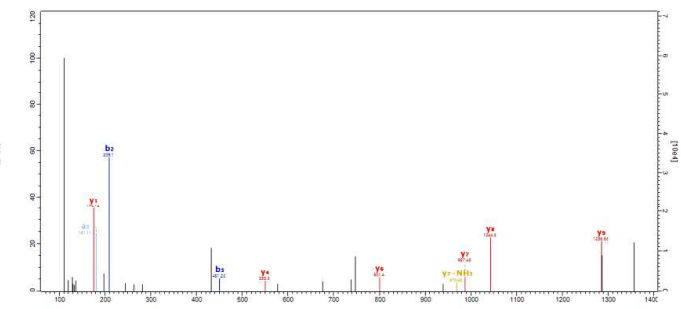

